\title{
Professional application innovation and personnel training and practice in the financial management of the Independent Institute
}

\author{
BIAN Rui ${ }^{1}$ \\ Department of Financial Management \\ Business School, Yunnan Normal \\ University \\ Kunming, China \\ E-mail: 332300418@qq.com
}

\author{
WU Dong-Rong ${ }^{2}$ \\ Department of Business \\ Administration \\ Business School, Yunnan Normal \\ University \\ Kunming, China \\ E-mail: 1313179@qq.com
}

\author{
YANG Hong-Tao ${ }^{3}$ \\ Department of Financial Management \\ Business School, Yunnan Normal \\ University \\ Kunming, China \\ E-mail: 542884787@qq.com
}

\begin{abstract}
-with the growing process of global economic integration, the application of innovative financial management talent to become the new darling of the society. Starting from the current financial management talents, to discuss the independent Institute of applied talents training mode, Applied Innovative Talents for financial management training practice situation, how to train optimize the financial management of the Independent Institute Professional Applied Innovative Talents actual operational advice.
\end{abstract}

Keywords- Independent Institute; applied financial management; personnel training

\section{INTRODUCTION}

Approved by the Ministry of National Education, the independent colleges in China have reached 323, enrollment accounted for a quarter of the Higher Education Undergraduate Admissions, and the Independent Institute has become an important part of private higher education. Into the 21st century, the society continues to heat up the multi-level needs of the higher education personnel training specifications. According to the data, more than $80 \%$ of senior professional positions need the application of innovative talents. At the same time, along with a number of undergraduate colleges have teaching university teaching and research or research into higher education personnel training of high-level applications neutral, independent colleges also found a good opportunity to seek dislocation development. It is based on the needs of the community and the students actually independent colleges train mode, to build the theory and practice of teaching system characterized by "application", on the basis of the knowledge transfer, focusing on the cultivation of the ability to "transform", the purpose of training students for lifelong learning capacity and innovation capability, students a comprehensive, coordinated and sustainable development.

\section{INDEPENDENT COLLEGES OF APPLIED FINANCIAL MANAGEMENT PERSONNEL TRAINING OBJECTIVES AND POSITIONING}

The community's overall quality of the applied talents: have noble ethics. The two have clear economic minds. Three have solid theoretical knowledge and skilled professional practices. Four should have a strong legal meaning. To the humanities. Six have good health and optimism mentality. According to the above application Talented requirements, independent colleges in the application of financial management personnel training objectives can be expressed as: training to adapt to the needs of socialist modernization, moral, intellectual and physical development, and with the management of economic, legal and financial management financial knowledge and ability, creative, complex and volatile financial management environment for the future strong adaptability, engaged in financial expertise and financial management applications in industrial, commercial and financial enterprises, institutions and government departments.

The professional aims to cultivate to master modern financial theory, engaged in capital operation, investment and financing planning, development of financial strategy and policy senior Finance talent. When students graduate, engaged in financial work and the discipline of teaching and research work in all kinds of companies, financial institutions, state-owned assets management, social insurance protection departments. The direction of the professional sub-culture, emphasizing innovation and practical ability of students. The lower grades culture the basis of professional, high-grade financial planning and corporate finance in both directions to students of professional competence.

\section{NDEPENDENT COLLEGES APPLIED INNOVATIVE FINANCIAL MANAGEMENT PROFESSIONAL PERSONNEL TRAINING}

After a decade of development, the development of independent colleges facing a "withdrawal" for which he seeks the key to sustainable development of future long-term health, "and", "turn" a different fate, connotative development strategy of the Independent Institute, which adhere to the personnel training strategy for cultivating highquality application-oriented talents as the main target is particularly critical.

Independent colleges with Chinese characteristics of private universities, undergraduate education supplement. This supplement is not only the enrollment scale on the amount of the supplement, but also the type of personnel 
training quality supplement. For now, independent collegetrained people should first social urgently needed, followed by application type, rather than research. But most local independent colleges existing training model can not meet the needs of local economic development strategies and local industry, there is a big gap between the original training model and curriculum needs of enterprises. Therefore, we need to explore new ideas applied innovative personnel training reform. The following table gives the public universities and independent colleges' professional settings identical ranking the top 10 professional:

\begin{tabular}{|c|c|c|c|}
\hline \multirow{2}{*}{ Stoverents' professionol } & \multicolumn{2}{|c|}{ Professionslponts (a) } & \multirow{2}{*}{$\begin{array}{l}\text { The professionalwith set } \\
\text { proportion (\%) } \\
\text { Independert College }\end{array}$} \\
\hline & Public Unirensities & Irdependert College & \\
\hline Frglikh & 576 & 229 & 78.4 \\
\hline $\begin{array}{l}\text { Computer Sciance and } \\
\text { Techrobog }\end{array}$ & 542 & 223 & 763 \\
\hline $\begin{array}{l}\text { Fitemutional Ecanomy and } \\
\text { Trade }\end{array}$ & 410 & 181 & 62 \\
\hline Art and Design & 400 & 188 & 643 \\
\hline Larr & 441 & 140 & 479 \\
\hline Marketing & 405 & 156 & 53.4 \\
\hline $\begin{array}{l}\text { Infromation Mfrnagement } \\
\text { ond frformation System }\end{array}$ & 395 & 125 & 428 \\
\hline $\begin{array}{l}\text { Electromic and hformation } \\
\text { Engineerimg }\end{array}$ & 364 & 138 & 473 \\
\hline Business fiministration & 362 & 137 & 469 \\
\hline Accourting & 339 & 127 & $43 s$ \\
\hline
\end{tabular}

Table 1 Independent Colleges and Public Universities professional same setting Compare

In a sample of 292 independent Institute more than half of the public colleges and universities are set the same professional points professional, such as nearly $80 \%$ of the schools set the English professional and computer science and technology professionals, the establishment of international economy and trade of the school has more than by $60 \%$.

Applied Innovative Talents core competitiveness is the ability to highlight, mainly in the science special ability and social development and the ability to innovate, such as foreign language skills, computer skills, science experiments, ability, thinking and judgment, language skills, social skills. Of ability must first develop rigorous evaluation standards, and is embodied in the whole process of teaching and school activities which, through evaluation, testing, competition, customs, standards, research or not fully demonstrated outstanding ability, to dare to institutional innovation, reform the curriculum system, the reform of teaching methods and means of reform and evaluation, reform incentives, to enable students to adapt to the ability to highlight "the cultivation of ideas. Table 2, below, personnel training, the SWOT matrix from S-O strategy, W-O strategy, S-T strategy and W-T strategy Independent Institute's internal factors affect the financial management professional applications innovation personnel training.

Based on the SWOT matrix analysis, the main problem is widespread by the Independent National Institute of Applied Innovative Personnel Training: (1), personnel training objectives are not clear, professional setting unreasonable. (2), curriculum system is imperfect, inadequate practical link. (3), weak faculty, structural contradiction. (4), students are relatively poor quality, individualized implement.

\begin{tabular}{|c|c|c|}
\hline Extemil fictors & 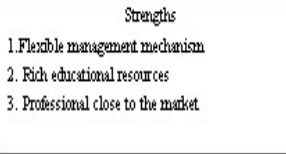 & \begin{tabular}{l}
\multicolumn{1}{c}{ Wealkuesses } \\
1.Poor the quality of studerts \\
2. Teachers with limited resources \\
3. Practice inadequate investmert \\
4. Weak teaching mid research
\end{tabular} \\
\hline $\begin{array}{l}\text { Oppontmities } \\
\text { 1.Policy-orierted } \\
\text { 2. Market demend }\end{array}$ & 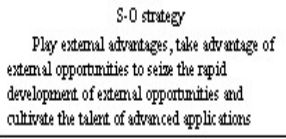 & 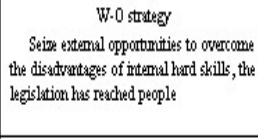 \\
\hline 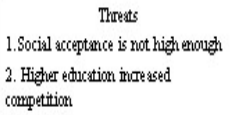 & $\begin{array}{c}\text { S.T I trateg } \\
\text { Ply intemal strengths to wovid extemal thrests }\end{array}$ & 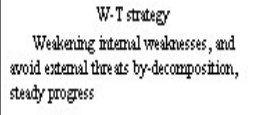 \\
\hline The overall conchsion of the analysis & \multicolumn{2}{|c|}{ The ittemal factors affect the independert Instinte for Applied Talents. Connotitive developmert. } \\
\hline
\end{tabular}

\section{THE CURRENT INDEPENDENT COLLEGES APPLIED \\ TALENTS TRAINING MODE UNIVERSAL MEASURES}

The basic principles of the Independent National Institute on the undergraduate application innovative training model and the measures taken in the following areas:

(1) To explore the characteristics of the students teaching mode. National Independent Institute in accordance with the social development and market demand, and constantly adjust the personnel training program, the establishment of a set of college talent cultivation positioning teaching system has its own characteristics and student learning characteristics. Are exploring the formation of the integration of knowledge, application and practice basic course in integrated education a compulsory subject, the quality of education classes, practical classes Four in the teaching mode.

(2) Build practical teaching system and implemented. The Independent National Institute in personnel training programs to develop the laboratory building to classroom teaching, teaching implement all aspects of practice.

(3) Introduction and cultivation "Double Type" Teachers, to build a strong faculty. Double Type "Teachers of the Independent Institute is working on building both academic standards and practical experience, and strengthen the sense of competition, establish and perfect a series of suitable higher education law, real science supporting teachers incentives.

(4) To the theory enough for standards, focusing on the cultivation of students' practical abilities. Ways and means to increase the time and intensity of the practice teaching, and the improvement of practice teaching, students have a greater ability to use this ability in addition to the professional and technical capacity, and should include job adaptability, innovation capability, capacity, survival and development capabilities, "wide base and strong ability to" fully reflects the characteristics. 


\section{STRENGTHEN FINANCIAL MANAGEMENT} PROFESSIONAL APPLICATIONS INNOVATION PERSONNEL TRAINING PRACTICE AND EXPLORATION

Analysis by experts and scholars from the major arguments aggregation and social needs of personnel training, financial management professional innovative training model applied to do the following two modes: (1) the overall training model. The overall goal of positioning the professional training in accordance with the educational philosophy and talent, "General Education --- Studies Foundation --- Specialty --- practical ability" basic training mode, learning and experimental implementation in the completion of a school classroom theory basics basis for training by cooperation campus wide range of businesses and institutions, form a complete set of application-oriented financial management training mode. (2), and professional personnel training mode. Actively implement "oriented to the needs of society, to cultivate a professional solid foundation, practical ability and comprehensive high quality applied talents" as the ultimate goal, according to the Application of The practical principles reorganization course structure, update teaching content and build new curriculum system, so that the basis of knowledge, quality guarantee, practical ability as the core practice base for relying on specialized training model.

Shown in Figure 1, innovative practice teaching prominent structures into "three classroom interaction" practice teaching system:

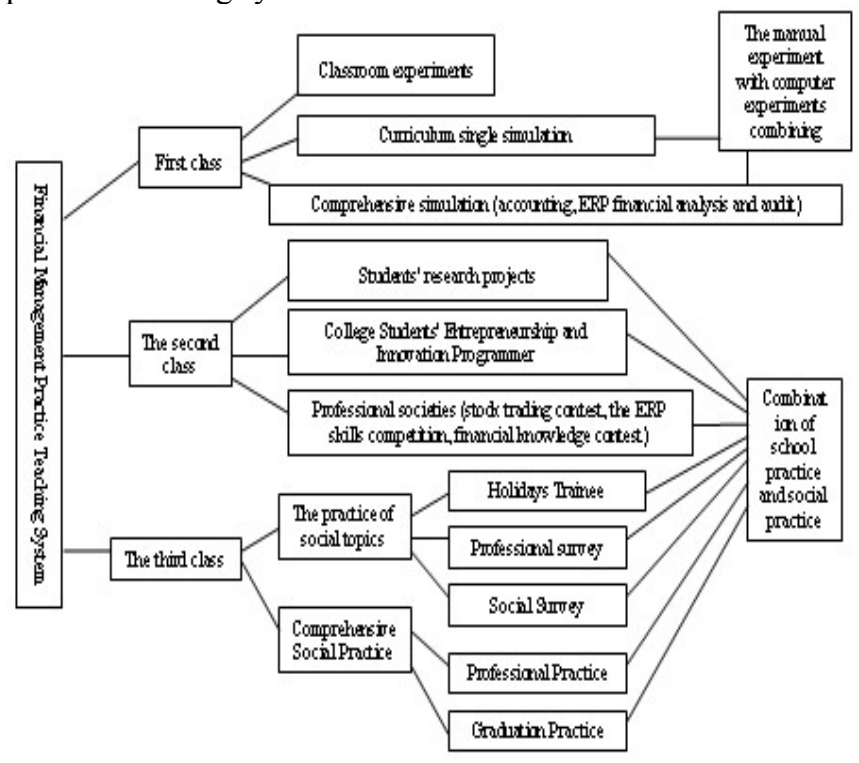

Figure 1 Financial management professional "three classroom interaction" practical teaching system

From the above analysis, it can be summed up in the practice of financial management professional applications innovation personnel training on the following aspects:

1) From the reality combined with the strategic development of independent college's further clarity the applied undergraduate student's personnel training target. From the outside, according to both the national education guidelines and policies, but also according to the social demand for talent. From internal analysis, according to the situation of the College's own resources, development goals, and to establish the characteristics of the College Applied Talents, the formation of the College's unique training model.

2) The characteristics given connotations, timely research and adjustment of the College Orientation and training specifications. Independent Colleges professional development process tends to the same home, the focus of analysis and a good grasp: First, the social culture of the independent Institute of talent needs accurate grasp of what talent is most scarce; second is the College school conditions and major advantage, to find out what kind of education for society, to cultivate what kind of talent; dare to putting in an effort to avoid the convergence of our trained people to fill vacancies in the talent market, outstanding innovation capacity and entrepreneurial ability, not compete with other independent colleges to eat, grab channel.

3) To strengthen the practice teaching, innovation and training process. Improve the practical teaching system, and stressed that the applied university is the nature and characteristics of the applied talents, applied innovation and personnel training should highlight the thicker foundation than wide caliber practice-oriented research should emphasize the application, especially with a strong secondary innovation and the quality of knowledge into and ability.

4) Improve personnel training system. Around the application of innovative talents training objectives, and constantly improve the personnel training objectives, training content, training process, develop specifications, specifications teaching and teaching management system, combined with the actual situation of the Institute to improve the teaching operation mechanism, so that teaching the theory and practice of the process of personnel training teaching link can be running smoothly, the greatest degree of implementation of the training objectives.

\section{REFERENCES}

[1] SHEN WeiJun, Financial management of teaching reform target of hate dimensional Jun-based Applied Talents.J. Higher Education Research, 2009 (1) .

[2] Shen Tu-Li. Innovation: fundamental independent college training model .J. Heilongjiang high teaching and research.Study, 2010 (8).

[3] Zhou Kaiyang, Judy, Jason Wu independent college talent training mode reform of practice and explorationCable .J.Chinese university teaching, 2010 (10).

[4] Liu XinChun, Zhang Cai-Zhi, application-oriented university financial management professional construction of thinking.J.ACCOUNTING 2010(3).

[5] Zhang Ai-Bang, SWOT analysis methods in university management.Shenyang Institute reported (Social Sciences).2006 (10) 471-473

[6] Yang Rui, Analysis of University Financial Management Professional Training Mode [J], Economist.2007(5). 